\title{
Tourism Development Strategy of Sukorambi Botanical Garden, Jember Regency-based on Tourist Perception
}

\author{
Daniar Putri Rahmawati ${ }^{1}$, Nuddin Harahab $^{2}$, Rita Parmawati ${ }^{3}$ \\ \{daniarputrir@gmail.com ${ }^{1}$, nuddin.harahab@gmail.com ${ }^{2}$, rita_parmawati@ub.ac.id ${ }^{3}$ \} \\ Universitas Brawijaya, Indonesia ${ }^{1,2,3}$
}

\begin{abstract}
Sukorambi Botanical Garden located in Jember Regency. This attraction is very unique because it combines natural and artificial tourism, viable to attract domestic and/or international tourists. The purpose of this research is to analyze the perceptions and expectations of tourists on the importance and performance of the management employees of Sukorambi Botanical Garden and formulate a strategy to develop Sukorambi Botanical Garden based on the level of perception and expectations of the tourist attraction. The data collection method was carried out through a survey with the research attributes that were compiled in the questionnaire. The level of perception and expectation of tourists to the level of importance and performance of all attributes in Sukorambi Botanical Garden as a whole were analyzed using the Customer Satisfaction Index (CSI) and the division of several research attributes to formulate development strategies were analyzed using Importance Performance Analysis (IPA). CSI results show a value of $74 \%$ which means "cause for concern" while the IPA results indicate that the main priority for the development strategy of Sukorambi Botanical Garden is to improve public facilities, optimize employee performance, develop restaurants and evaluate employee performance regularly.
\end{abstract}

Keywords: Customer Satisfaction Index, Importance Performance Analysis, Sukorambi Botanical Garden.

\section{Introduction}

Indonesia has a diversity of abundant natural resources, both biological and non-biological [1]. Wealth of biological natural resources can be seen from the many types of flora and fauna while the wealth of non-biological natural resources can be seen from the abundant oil, metal and natural gas resources in several locations in Indonesia [2]. The diversity of biological resources that are abundant can lead to the potential of nature tourism which is expected to have good prospects in Indonesia. According to Yoeti [3], fifty-two percent of Indonesia's tourism assets are types of nature tourism. Therefore, to develop tourism in Indonesia, it is necessary to have a sustainable and environmentally friendly tourism development. One form of natural tourism in Indonesia is agritourism. Agritourism can be interpreted as a form of tourism activities that implement agribusiness as a tourist attraction with a view to expanding knowledge, recreation, and business relationships in agriculture [3][4].

In the era of regional autonomy, agritourism can be developed by each region, by presenting attractions that are specific to the culture and conditions of the region. One of the agritourism 
developed with the aim of playing and learning is the botanical garden [5]. One of the developing cities in Indonesia that has a botanical tourism garden is Jember Regency. Jember Regency is a district that has great potential in developed of agritourism. Jember Regency has an area of $3,293.34 \mathrm{~km}^{2}$ with altitudes between $0-3,330$ meters above sea level and has a tropical climate with a temperature range of $23-32^{\circ} \mathrm{C}$ which is very potential to be used as an agritourism city [6].

One of the nature tourism areas in Jember Regency which has implemented the concept of agritourism as a playground and learning as their business unit is Sukorambi Botanical Garden [7]. Inside Sukorambi Botanical Garden there are sharing of artificial tourism rides, such as fishing ponds, swimming pools, flying fox and others as well as organic fruit and vegetable picking tours as a natural attraction. However, in carrying out this agritourism business activity, Sukorambi Botanical Garden faces various obstacles, namely the presence of competitors and fluctuations in amount of the tourists who cannot be predicted and vary each day due to various internal and external factors [6].

One internal factor generally comes from the quality of services provided to consumers and one external factor is the customer's satisfaction with the quality of the importance and performance of the company. Service quality is everything that focuses on a variety of businesses to meet the needs and desires of consumers accompanied by accuracy in delivering it so as to create a balanced match with consumer expectations [8]. If the service received is as expected, the quality of service will be perceived as good and satisfying. If the service received does not meet consumer expectations, the perceived quality of service is bad or poor. Thus, good or bad quality of service depends on the ability of service providers to consistently meet consumer expectations and end up in the perception of these consumers. If tourist satisfaction is fulfilled, the desire to return to the same place will be even greater [9].

In 2018, the number of visitors at Sukorambi Botanical Garden is very fluctuating, this shows that the competitiveness of agritourism with other tourist attractions (both natural and artificial tourism) is increasing. This is a threat to the management and employees of Sukorambi Botanical Garden, because the existence of a tourist attraction is very dependent on the number of tourists. Therefore, Sukorambi Botanical Garden must to requires a strategy of developing a good tourism park to maintain and develop its business, both from management, attractions, cleanliness, tourist attractions and others that must be developed to attract tourists, so that Sukorambi Botanical Garden can be used as environmentally sustainable tourism park.

\section{Research Methods}

\subsection{Study Area}

Sukorambi Botanical Garden (TBS) located on Mujahir Street, Sukorambi Village, Krajan Village, Sukorambi District, Jember Regency, East Java. Geographically, this tourist location is at the foot of Mount Argopuro. Sukorambi Botanical Garden is located approximately $7 \mathrm{~km}$ west of Jember Regency. Sukorambi Botanical Garden is a natural and artificial tourist location located closest to the center of Jember. This park has the main concept of "Recreation While Learning". This park has an area of around 8 hectares and presents a diverse collection of plants, animals, games and rides that can be enjoyed by the tourist of all ages. The main objective of the founder of TBS is to become one of the conservation institutions that can bridge the government in inviting the community to be environmentally conscious [7]. 
Some artificial tourist rides offered for the visitors of Sukorambi Botanical Garden are tree houses, flying fox, various outbound games, Muslim woman swimming pools, adult pools, children's pools, duck boats, reading huts, horse riding and others. Sukorambi Botanical Garden also offers learning facilities for tourists because there are collections of approximately 500 species of flora and fauna, bunny and friend villages, various collections of ornamental animals and protected animals and hatchery koi fish and freshwater crayfish. Uniquely, all the water used in Sukorambi Botanical Garden comes from seven natural springs that flow within this tourist site. In addition, this tour has a large parking lot, a hall for meetings or weddings, a barbecue area, art huts, several gazebo's under shady trees, restaurants, golf carts, villas, open stages for live music, public and VIP bathrooms and also the bathrooms for diffable tourist [7].

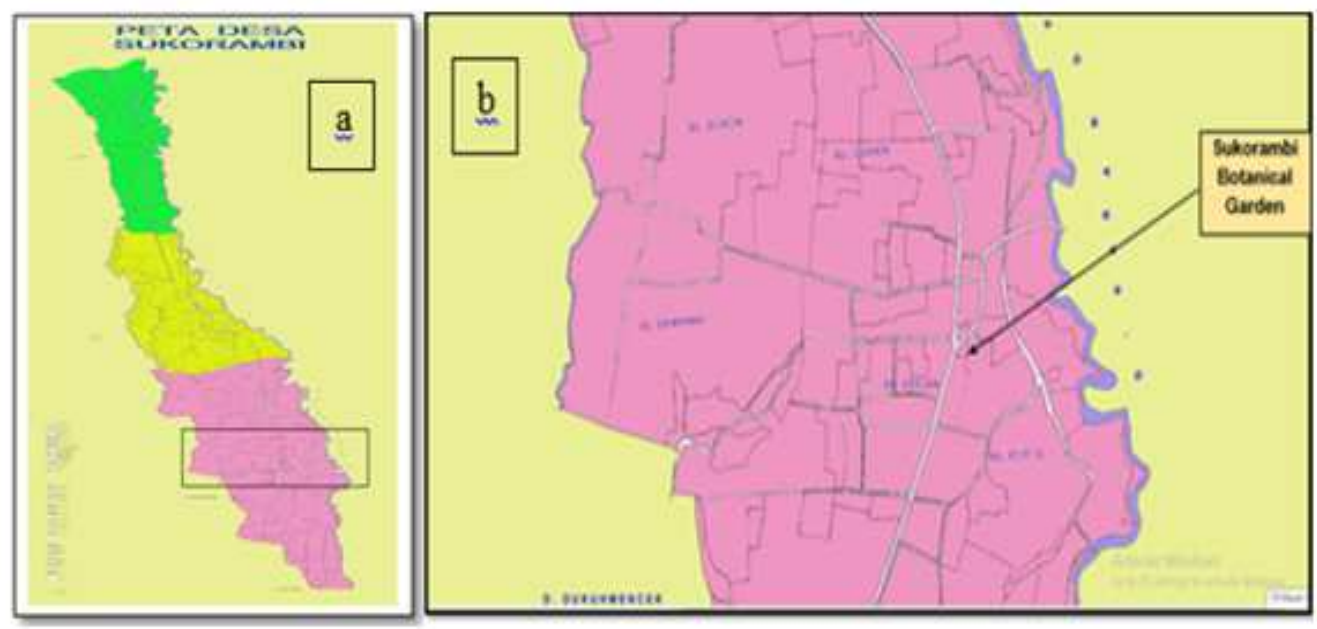

Description:

Fig. 1. Study Area of Sukorambi Botanical Garden [10].

a) Sukorambi Village Map.

b) The location of the Sukorambi Botanical Garden.

\section{Data Analysis}

This study was conducted for one month which was from June to July 2019. The number of samples taken is determined using the "Linear Time Function" formula $\left(T=t_{0}+t_{1 n}\right)$. The number of samples in this formula is determined based on the effective time used to carry out the study because the population is unknown in number [11]. Data collection was conducted through a survey by distributing questionnaires to 70 respondents who visited in Sukorambi Botanical Garden.

The survey used questionnaires that have been prepared in a structured and systematic way based on five dimensions of service quality/SERVQUAL that is: tangible, reliability, responsiveness, assurance, dan empathy. Those attributes are as follows in Table 1.

Table 1. Research Attributes/Five Dimensions of Service Quality (SERVQUAL)

\begin{tabular}{ccc}
\hline Dimension & Code & Interpretation \\
\hline Tangible & A1 & Variation and uniqueness of natural resources
\end{tabular}




\begin{tabular}{|c|c|c|}
\hline & A2 & Variations and quality of artificial vehicles \\
\hline & A3 & Completeness and quality of infrastructure \\
\hline & A4 & Price of admission, foods and drinks \\
\hline & A5 & Appearance of all employees \\
\hline \multirow{4}{*}{ Reliability } & A6 & The timeliness of open and close of this place \\
\hline & A7 & Ease of tourists in conducting various transactions (cash or debit) \\
\hline & A8 & $\begin{array}{l}\text { The reliability of all employees to respond the requests, criticisms } \\
\text { and suggestions from the tourists }\end{array}$ \\
\hline & A9 & $\begin{array}{l}\text { Ease of providing information about Sukorambi Botanical Garden } \\
\text { through various media (online, sound and print) conducted by the } \\
\text { employee }\end{array}$ \\
\hline \multirow[t]{5}{*}{ Dimension } & Code & Interpretation \\
\hline & A10 & $\begin{array}{l}\text { Employee's knowledge of various matters relating to Sukorambi } \\
\text { Botanical Garden }\end{array}$ \\
\hline & A11 & $\begin{array}{l}\text { The logo and names of Sukorambi Botanical Garden restaurant that } \\
\text { can attract the tourists to come }\end{array}$ \\
\hline & A12 & $\begin{array}{l}\text { The reliability of restaurant waiters in serving food and drinks that } \\
\text { ordered by the tourists }\end{array}$ \\
\hline & A13 & Variations of food and drinks offered at the restaurant \\
\hline \multirow{3}{*}{ Responsiveness } & A14 & $\begin{array}{l}\text { The handiness of employees in responding to requests, complaints, } \\
\text { criticisms and suggestions from the tourists }\end{array}$ \\
\hline & A15 & $\begin{array}{l}\text { The way of communication and interaction between employees and } \\
\text { tourists }\end{array}$ \\
\hline & A16 & $\begin{array}{l}\text { Capability to respond the tourist arrivals by Sukorambi Botanical } \\
\text { Garden employees }\end{array}$ \\
\hline \multirow{5}{*}{ Assurance } & A17 & Sukorambi Botanical Garden image in the eyes of the public \\
\hline & A18 & $\begin{array}{l}\text { The safety of travelers' luggage while at Sukorambi Botanical } \\
\text { Garden }\end{array}$ \\
\hline & A19 & CCTV cameras provide a sense of security for the tourists \\
\hline & $\mathrm{A} 20$ & $\begin{array}{l}\text { Feeling safe and comfortable when doing tourist activities against } \\
\text { the risk and safety of themselves and the people around them by } \\
\text { tourists }\end{array}$ \\
\hline & $\mathrm{A} 21$ & Communication guarantee for the tourists \\
\hline \multirow{3}{*}{ Empathy } & A22 & $\begin{array}{l}\text { Attention that's given to individuals/groups concerned (tourists) by } \\
\text { Sukorambi Botanical Garden employees }\end{array}$ \\
\hline & A23 & $\begin{array}{l}\text { The behavior of Sukorambi Botanical Garden employees to all } \\
\text { tourists }\end{array}$ \\
\hline & A24 & $\begin{array}{l}\text { Equality of services provided by Sukorambi Botanical Garden } \\
\text { employees }\end{array}$ \\
\hline
\end{tabular}

\subsection{Customer Satisfaction Index}

CSI is an index to determine the level of overall customer satisfaction with the company's service performance with an approach that considers the importance of the measured product or service attributes [9]. In this research, CSI is used to measure the level of overall tourist satisfaction attributes with the importance and performance of Sukorambi Botanical Garden employees. The equation for this method is: 
a) Calculating Weighted Factor (WF): change the average value of importance to a percentage of the total average importance of all attributes tested, so that a total WF of $100 \%$ is obtained.

b) Calculating Weighting Score (WS): assessing the multiplication between the average value of the performance level of each attribute and the WF of each attribute.

c) Calculating Weighted Total (WT): sums the WS of all attributes.

d) Calculating the Satisfaction Index: WT divided by the maximum scale used (in this study the maximum scale used is 5), then multiplied by $100 \%$, upon the following equations:

$$
\mathrm{CSI}=\frac{\sum_{k=1}^{p} W S}{H s} \times 100 \%
$$

Hs $($ Highest Scale $)=$ the maximum scale used. In this study the maximum scale used is 5 .

The overall level of satisfaction of respondents can be seen from the level of satisfaction criteria in Table 2.

Table 2. Customer Satisfaction Index Interpretation

\begin{tabular}{cc}
\hline Index & Interpretation \\
\hline $\mathrm{X} \leq 64 \%$ & Very Poor \\
$64 \%<\mathrm{X} \leq 71 \%$ & Poor \\
$71 \%<\mathrm{X} \leq 77 \%$ & Cause for Concern \\
$77 \%<\mathrm{X} \leq 80 \%$ & Borderline \\
$80 \%<\mathrm{X} \leq 84 \%$ & Good \\
$84 \%<\mathrm{X} \leq 87 \%$ & Very Good \\
$87 \%<\mathrm{X}$ & Excellent \\
\hline Description: $\mathrm{X}=$ Customer Satisfaction Index Numbers (CSI Index) $[12]$.
\end{tabular}

\subsection{Importance Performance Analysis (IPA)}

This method was used to analyze tourists' perceptions towards the attributes of tourism objects' performances in order to formulate a tourism development strategy [13] in Sukorambi Botanical Garden. IPA is a combination of perceptions towards the satisfaction and importance level [12]. Using a Likert scale with 5 different levels: very unimportant, unimportant, rather important, important, and very important [14]. The equation for this method is:

Description:

$$
\mathrm{T}_{\mathrm{ki}}=\frac{\mathrm{Xi}}{\mathrm{Yi}} \times 100 \%
$$

$\mathrm{T}_{\mathrm{ki}}=$ parallel level

$\mathrm{Xi}=$ satisfaction score

$\mathrm{Yi}=$ importance score

Furthermore, in the Cartesian coordinate diagram, the $\mathrm{X}$ axis in the satisfaction level, whereas, the $\mathrm{Y}$ axis is the importance level based upon the following equations. 


$$
\overline{X i}=\frac{\sum_{i=1}^{k} \overline{X i}}{n} \quad \bar{Y} i=\frac{\sum_{i=1}^{k} \overline{Y i}}{n}
$$

Description:

$\mathrm{X}=$ average score for satisfaction level

$\mathrm{Y}=$ average score for importance level

$\mathrm{n}=$ number of respondents

To determine the objective margins represented by the coordinate of $\mathrm{x}, \mathrm{y}$, the following equations were used.

$$
\overline{\overline{X i}}=\frac{\sum_{i=1}^{k} \overline{X i}}{k} \quad \overline{Y i}=\frac{\sum_{i=1}^{k} \bar{Y} i}{k}
$$

Description:

$\mathrm{K}=$ number of items or attributes scored by the respondents

Consecutively, the average scores were then mapped in the Cartesian coordinate diagram which had been divided into 4 sections or quadrants (Fig. 2).

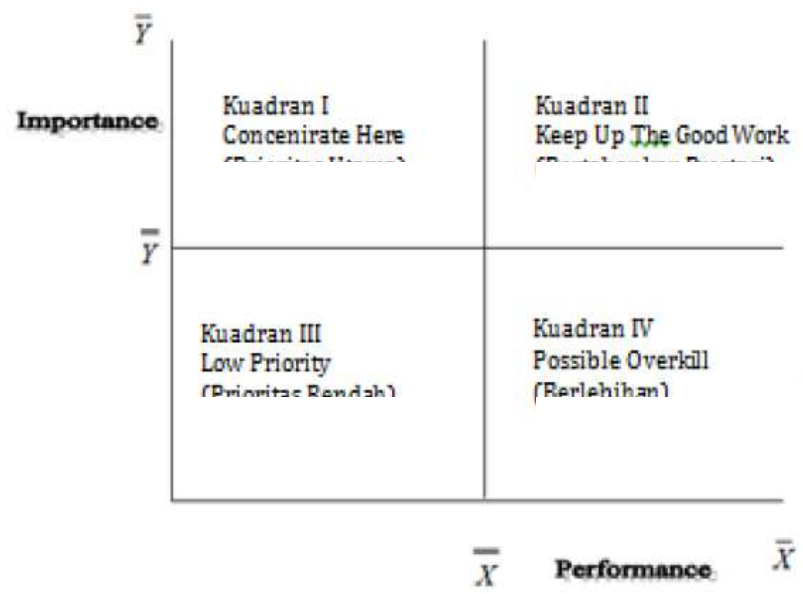

Fig. 2. IPA Cartesian Coordinate Diagram [15].

\section{Result and Discussion}

\subsection{Tourist Satisfaction Level Based on Analysis of Customer Satisfaction Index (CSI)}

Customer Satisfaction Index (CSI) analysis technique is used to measure the level of tourist satisfaction with the level of importance and performance of the Sukorambi Botanical Garden employees as a whole. CSI analysis calculation table is presented in table 3.

Table 3. CSI Analysis Results 


\begin{tabular}{cccc}
\hline $\begin{array}{c}\text { Attribute } \\
\text { Number }\end{array}$ & $\begin{array}{c}\text { Importance Level } \\
(\mathrm{I})\end{array}$ & $\begin{array}{c}\text { Performance Level } \\
(\mathrm{P})\end{array}$ & $\begin{array}{c}\text { Score (S) } \\
(\mathrm{I} \mathrm{X} \mathrm{P)}\end{array}$ \\
\hline A1 & 3,96 & 3,61 & 14,30 \\
A2 & 3,97 & 3,56 & 14,13 \\
A3 & 3,91 & 3,51 & 13,72 \\
A4 & 3,86 & 3,57 & 13,78 \\
A5 & 3,91 & 3,66 & 14,31 \\
A6 & 3,94 & 3,77 & 14,85 \\
A7 & 3,93 & 3,66 & 14,38 \\
A8 & 3,91 & 3,54 & 13,84 \\
A9 & 4,01 & 3,77 & 15,12 \\
A10 & 3,91 & 3,64 & 14,23 \\
A11 & 3,86 & 3,59 & 13,86 \\
A12 & 3,87 & 3,64 & 14,09 \\
A13 & 3,73 & 3,49 & 13,02 \\
A14 & 3,97 & 3,71 & 14,73 \\
A15 & 3,96 & 3,71 & 14,69 \\
A16 & 4,07 & 3,79 & 15,43 \\
A17 & 4,03 & 3,81 & 15,35 \\
A18 & 4,07 & 3,80 & 15,47 \\
A19 & 4,06 & 3,80 & 15,43 \\
A20 & 4,09 & 3,87 & 15,83 \\
A21 & 4,09 & 3,79 & 15,50 \\
A22 & 4,01 & 3,71 & 14,88 \\
A23 & 4,11 & 3,80 & 15,62 \\
A24 & 4,13 & 3,84 & 15,86 \\
\hline Total & 95,36 & 88,64 & 352,41 \\
\hline
\end{tabular}

From the data presented in the table 3 , it can be calculated the value of customer satisfaction as tourists in Sukorambi Botanical Gardens as follows:

$$
\begin{aligned}
& \mathrm{CSI}=\frac{\sum_{k=1}^{p} W S}{H S} \times 100 \% \\
& \mathrm{CSI}=\frac{352,41}{5 \times 95,36} \times 100 \% \\
& \mathrm{CSI}=74 \%
\end{aligned}
$$

Based on the CSI analysis from Sukorambi Botanical Garden tourist's, the CSI value was $74 \%$. According to the customer satisfaction index/CSI table previously described [12], a CSI value of $71 \%<\mathrm{X} \leq 77 \%$ means that "Cause for Concern". This shows that the perception and expectation of Sukorambi Botanical Gardens tourists to the five dimensions of service quality 
(SERVQUAL) provided by employees as a whole cannot be said to be "satisfactory" and the service attributes still need to get "more attention" to continue to be improved.

According to Aritonang [12], when performance is in line with expectations, tourists will feel "satisfied" and when performance exceeds expectations, consumers will feel "very satisfied". The value of CSI can be improved by making improvements to the performance of the attributes of the results of the Importance Performance Analysis (IPA). The improvement of attributes obtained through IPA analysis is expected to increase the value of CSI up to $100 \%$.

\subsection{Tourist Satisfaction Level-based on Importance Performance Analysis (IPA)}

The Importance Performance Analysis (IPA) technique is used to see the extent of the company's achievements and what attributes need to be maintained and improved by the company (Sukorambi Botanical Garden). The table of IPA analysis is presented in Table 4 and the Cartesian Diagram of IPA (Fig. 3).

Table 4. IPA Analysis Results

\begin{tabular}{cccccc}
\hline $\begin{array}{c}\text { Attribute } \\
\text { Number }\end{array}$ & $\begin{array}{c}\text { Performance } \\
\text { Score }\left(\mathrm{X}_{\mathrm{i}}\right)\end{array}$ & $\begin{array}{c}\text { Average of } \\
\text { Performance } \\
\text { Score }\end{array}$ & $\begin{array}{c}\text { Importance } \\
\text { Score }\left(\mathrm{Y}_{\mathrm{i}}\right)\end{array}$ & $\begin{array}{c}\text { Average of } \\
\text { Importance } \\
\text { Score }\end{array}$ & $\begin{array}{c}\text { Suitability } \\
\text { Level }\left(\mathrm{T}_{\mathrm{ki}}\right) \%\end{array}$ \\
\hline A1 & 274 & 3,91 & 288 & 4,11 & 95,14 \\
A2 & 270 & 3,86 & 280 & 4 & 96,43 \\
A3 & 264 & 3,77 & 285 & 4,07 & 92,63 \\
A4 & 269 & 3,84 & 284 & 4,06 & 94,72 \\
A5 & 270 & 3,86 & 281 & 4,01 & 96,09 \\
A6 & 268 & 3,83 & 286 & 4,09 & 93,71 \\
A7 & 272 & 3,89 & 288 & 4,11 & 94,44 \\
A8 & 271 & 3,87 & 286 & 4,09 & 94,76 \\
A9 & 269 & 3,84 & 283 & 4,11 & 95,05 \\
A10 & 273 & 3,9 & 287 & 4,09 & 95,12 \\
A11 & 262 & 3,74 & 271 & 4,04 & 96,68 \\
A12 & 261 & 3,73 & 279 & 4,1 & 93,55 \\
A13 & 259 & 3,7 & 271 & 3,87 & 95,57 \\
A14 & 291 & 4,16 & 282 & 3,99 & 103,19 \\
A15 & 267 & 3,81 & 274 & 3,87 & 97,45 \\
A16 & 268 & 3,83 & 278 & 4,03 & 96,40 \\
A17 & 273 & 3,9 & 287 & 3,91 & 95,12 \\
A18 & 269 & 3,84 & 289 & 3,97 & 93,08 \\
A19 & 265 & 3,79 & 282 & 4,1 & 93,97 \\
A20 & 272 & 3,89 & 286 & 4,13 & 95,10 \\
A21 & 271 & 3,87 & 282 & 4,03 & 96,10 \\
A22 & 270 & 3,86 & 283 & 4,04 & 95,41 \\
& & & & &
\end{tabular}




\begin{tabular}{cccccc} 
A23 & 268 & 3,83 & 285 & 4,07 & 94,04 \\
A24 & 276 & 3,94 & 286 & 4,09 & 96,50 \\
\hline Total & 6472 & 92,46 & 6783 & 96,98 & 95,43 \\
\hline Average & 3,85 & & 4,04 & \\
\hline
\end{tabular}

Mapping on Cartesian diagram exhibited number of attributes. Based on the figure, there are attributes that requires improvement and maintenance, divided into quadrants (A/I, B/II, C/III, and D/IV) according to suitability level between tourist importance level and employee's performance level presented in Figure 3.

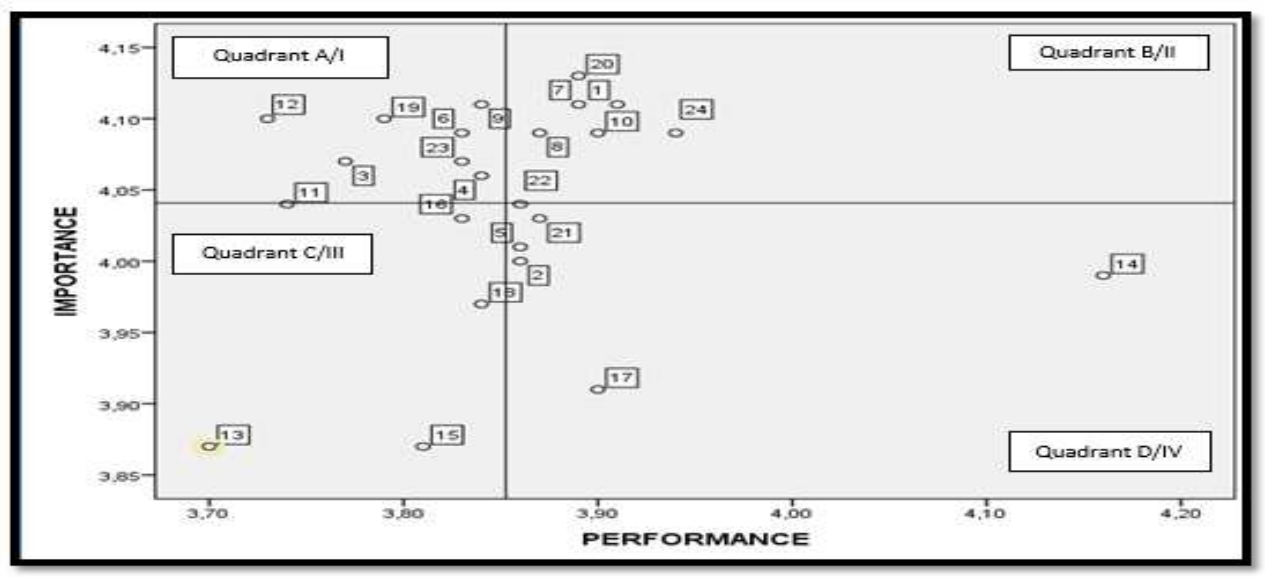

Fig. 3. IPA Cartesian Coordinate Diagram.

\subsection{Tourism development strategy based on the perception of Sukorambi Botanical Garden}

Based on the IPA analysis, the alternative strategy for tourism development in Sukorambi Botanical Garden can be elaborated to the following:

\subsubsection{Quadrant A/I, Concentration here/main priority (high importance, low satisfaction)}

Quadrant A/I contain attributes that are considered important by tourists, but the quality of their services has not met their expectations [13]. The tourist attraction must try to improve the attributes in this quadrant to increase customer satisfaction. Based on the Cartesian diagram, the attributes that include into this quadrant are A3, A4, A6, A9, A11, A12, A19, and A23. The development strategy is:

a) Improve and increase public facilities such as toilets, mini cars, mini market, trash bins, gazebo, and parking area, especially for four or more wheeled vehicles.

b) Develop restaurants and accommodations.

c) Develop a gift shop.

d) Additional counter attendants required.

e) Addition and improvement of a more detailed information system is needed to fund attractions, entrance fees, food and beverage prices and various other tourism promos, through social media, print or other media. 
f) Names and logos that are unique to restaurants are required.

g) More intensive training is needed for extra supervision of waiters and chefs in restaurants.

h) Required the addition of CCTV cameras in some strategic locations such as parking areas, swimming pools and several other areas to provide a sense of security for tourists.

i) Improve the periodically evaluating for all employees by the Sukorambi Botanical Garden management.

\subsubsection{Quadrant B/II, keep up the good work/keep achievement (both high importance and satisfaction level)}

Quadrant B/II contain attributes considered important by the tourists, and met their expectation. Therefore, it resulted in higher tourist satisfaction. With high tourist satisfaction level in this quadrant, tourist attraction party should maintain these attributes in order to satisfy the tourist according to their expectation [13]. Based on the Cartesian diagram, the attributes that include into this quadrant are A1, A7, A8, A10, A20, A22, and A24. The development strategy is:

a) Preserve and maintain the uniqueness and variety of existing natural resources.

b) Maintaining ease of transaction for tourists and increasing cooperation with other parties related to the virtual or online transaction system.

c) Maintaining infrastructure such as roads (access), drainage, water supply and communication networks.

d) Maintaining the reliability of all employees in responding to requests, criticisms and suggestions from tourists.

e) Maintaining community participation by involving them in the process of restoration and environmental preservation.

f) Maintaining employee knowledge about various types of matters relating to attractions.

g) Maintaining everything that makes tourists feel safe and comfortable while doing tourist activities in Sukorambi Botanical Garden against the risk and safety of themselves and the people around them.

h) Maintain the attention that given to the tourists (individuals/groups) concerned by the employee.

i) Maintaining equality of services provided by Sukorambi Botanical Garden employees to all tourists.

j) Maintaining all types of attractions to increase tourist attraction

\subsubsection{Quadrant C/III, low priority (low important and satisfaction level)}

Quadrant C/III contain attributes tourists considered unimportant and possess dissatisfying performance level from tourist object party [13]. Nevertheless, these aspects could become more important in the future. Therefore, tourist attraction party should consider improving the attributes. Based on the Cartesian diagram, the attributes that include into this quadrant are A13, A15, A16 and A18. The development strategy is:

a) Provides access to public transportation to objects for easier accessibility.

b) Provides additional tour guide services.

c) Increasing the variety of foods and drinks offered at restaurants, especially healthy foods whose raw materials come from the green house or Sukorambi Botanical Garden (TBS) fishing pond so that tourists are more familiar with this and have an interest in a variety of TBS vegetable, fruit and fish products. 
d) Improve training for all employees who cannot speak Indonesian properly and correctly and provide foreign language training (minimum English) to all employees of TBS to make it easier for tourists when they need direct interaction with TBS employees.

e) Give direction to the employees, especially employees of the ticket window/entrance to be more agile in responding to the arrival of tourists, especially tourists with two-wheeled vehicles without distinguishing one another.

f) Add more luggage storage facilities (with special guards) and more privacy storage cabinets with individual keys that can be carried by tourists in order to increase the sense of security and comfort for traveler's luggage.

\subsubsection{Quadrant IV, possible to overkill/excessive (low importance level, yet high satisfaction level)}

Quadrant IV contain attributes that are considered not important by tourists and are too maintained or have too high a level of performance [13]. No further treatment needed. Attributes in quadrant IV are attributes that are very well maintained in Sukorambi Botanical Garden (TBS), but are considered to be of little importance so that they appear to be overdoing it. TBS is advised to allocate its resources for top priority. Based on the Cartesian diagram, the attributes included in this quadrant are A2, A5, A14, A17 and A21. The development strategy is:

a) Maintaining the quality of various artificial tours in TBS.

b) Maintaining the appearance of all TBS employees.

c) Maintaining the agility of the managers and employees of TBS in responding to requests, complaints, criticism and suggestions from tourists.

d) Maintaining the image of TBS in the eyes of the community,

e) Maintaining communication guarantees (cellular network affordability) for tourists in TBS.

\section{Conclusion}

Based on the Customer Satisfaction Index (CSI) analysis known that CSI values is $74 \%$, were obtained where a CSI value of $71 \%<\mathrm{X} \leq 77 \%$ was interpreted as "Cause for Concern" or "Needing More Attention". From the results of the Importance Performance Analysis (IPA), there are 8 attributes included in quadrant I/A, 7 attributes in quadrant II/B, 4 attributes in quadrant III/C and 5 attributes in quadrant IV/D.

\subsection{Recomendations}

a) Hoped that the management of Sukorambi Botanical Garden (TBS) can improve, maintain, select and pay more attention to all attributes in accordance with their respective quadrants that have been outlined in the CSI and IPA analysis, so TBS can become a environmentally sustainable tourism park, attract more interest for community travel, both in Jember Regency and outside of it.

b) It's expected that TBS management can apply the "Complaints and Suggestions System" method to measure tourist satisfaction directly, one of which is to pay attention and provide broad opportunities for tourists to submit their suggestions, opinions and complaints. The media used are usually by providing suggestion boxes, comment cards, customer service systems listed on the official website or the other of TBS's social media and jumping 
directly into the field and so forth. This information can provide brilliant ideas for the TBS management and allows it to react quickly to overcome problems, criticisms or suggestions felt by tourists.

c) Management of TBS requires further study to add important input to tourism activities.

d) TBS also needs input and support from the government and other agencies related to local tourism to develop various tourism objects in it (natural or artificial) because good cooperation between stakeholders, both private and government of Jember Regency is expected to make TBS into an environmentally sustainable tourism park.

\subsection{Acknowledgement}

The authors would like to thank the Master Program of Environmental Resources Management and Development, Interdisciplinary Graduate Program, Faculty Non Faculty, Brawijaya University, Malang that assist authors in providing inputs, especially Prof. Dr. Ir. Nuddin Harahab, MP and Dr. Rita Parmawati, SP., ME.

\section{References}

[1] N. S. Pendit, “Tourism Science; A Prime Introduction.” Jakarta: Pradnya Paramita, 2006.

[2] E. Yustina, R. Avenzora, and T. Sunarminto, "Analysis of Perception towards Ecology in Ecotourism Development in Sleman Regency," Media Konserv., vol. 22, no. 3, pp. 262-268, 2017.

[3] O. A. Yoeti, "Pengantar ilmu kepariwisataan," Bandung: Pradya Paramita, 1996.

[4] M. A. Ridlwan, S. Muchsin, and H. Hayat, "Model Pengembangan Ekowisata dalam Upaya Pemberdayaan Masyarakat Lokal," Polit. Indones. Indones. Polit. Sci. Rev., vol. 2, no. 2, pp. 141$158,2017$.

[5] D. Syarizka, I. Agustine, and S. Munowaroh, Development of Priority Tourist Destinations. Indonesian Business. Jakarta: Jurnalindo Aksara Grafika, 2018.

[6] D. D. Pratiwi, "Kualitas Pelayanan dan Daya Tarik Objek Wisata dalam Upaya Meningkatkan Minat Wisatawan pada Taman Botani Sukorambi Jember," Thesis Univ. Jember, 2015.

[7] Taman Botani Sukorambi, "Official Website of Sukorambi Botanical Garden," Taman Botani Sukorambi, 2019. [Online]. Available: https://tamanbotanisukorambi.com/.

[8] E. Azzopardi and R. Nash, "A critical evaluation of importance-performance analysis," Tour. Manag., vol. 35, pp. 222-233, 2013.

[9] K. Matzler, F. Bailom, H. H. Hinterhuber, B. Renzl, and J. Pichler, "The asymmetric relationship between attribute-level performance and overall customer satisfaction: a reconsideration of the importance-performance analysis," Ind. Mark. Manag., vol. 33, no. 4, pp. 271-277, 2004.

[10] Sukorambi District Jember Regency, "Potensi Desa," Official Website of Sukorambi Village Goverment, Sukorambi District, Jember Regency, 2018. [Online]. Available: https://sukorambidesa.wordpress.com/potensi-desa/.

[11] J. A. Mateka, "The analysis of the demand of visitors towards attractions in Balekambang Beach Malang.” Thesis. Faculty of Fisheries and Marine Sciences. University of Brawijaya ..., 2013.

[12] R. L. Aritonang, "Pemasaran jasa dan kualitas pelayanan.” Bayumedia Publishing, Malang, 2005.

[13] V. V. S. Timang, A. Antariksa, and I. R. D. Ari, "Tourism Development Strategy of Buntula'bi Balusu Sub-Village, North Toraja Regency Based on Tourist Perception,” J. Indones. Tour. Dev. Stud., vol. 2, no. 3, p. 95, 2014

[14] Sugiyono, Metode Penelitian Kuantitatif, Kualitatif dan $R \& D$. Bandung: Anggota Ikatan Penerbit Indonesia (AIPI), 2013.

[15] D. R. Bacon, "A comparison of approaches to importance-performance analysis," Int. J. Mark. Res., vol. 45, no. 1, pp. 1-15, 2003. 
